\title{
Socio-economic effect on socially-deprived communities of developing drinking water quality problems in arid and semi- arid area of central Rajasthan
}

\author{
I. HUSAIN 1 , J. HUSAIN ${ }^{2}$ \& M. ARIF ${ }^{3}$ \\ 1 Public Health Engineering Department, Rajasthan, Bhilwara, 311001 India \\ ikbalhusain@gmail.com \\ 2 NW Region, Central Ground Water Board, Ministry of Water Resources, Chandigarh, 160019 India \\ 3 Department of Chemistry, Banasthali University, Tonk, India
}

\begin{abstract}
Rajasthan is well known for its Great Thar desert. Central Rajasthan has an arid to semi-arid environment. The area faces either scarcity of water or poor quality of drinking water. In some areas water is transported $2 \mathrm{~km}$ or more, which uses time, energy and money. Rich people have their own sources, which is restricted for use by others. Such conditions are affecting socially-deprived communities, both socially and economically. Groundwater is a major source of drinking water due to the unavailability of surface water. There is a lack of groundwater quality knowledge in the community and the data available is hard to understand by consumers. The CCME Water Quality Index is a tool to simplify the water quality report by rating the water on quality standards. It provides meaningful summaries of overall water quality and trends, which is accessible to non-technical lay people. In the present study the objective is to examine the groundwater quality of six districts (Ajmer, Bhilwara, Pali, Rajasamand, Nagaur and Jodhpur), centrally located in Rajasthan, with arid and semi-arid conditions. CCME WQI is also evaluated to produce quality data in a form to be understood by the community. A total of 4369 groundwater sources in 1680 villages from six districts $\left(76546 \mathrm{~km}^{2}\right)$ were collected and examined. Results are outlined in the Bureau of Indian Standards (BIS: 10500, 2012) and 2952 sources are unsafe for drinking. According to CCME WQI groundwater of 93 villages is poor, 343 villages are marginal, and 369 villages are fair in quality. Toxicological studies of unsafe drinking water and their remedial measures are also discussed. A tentative correlation between prevailing water-borne diseases and quality parameter has also been shown.
\end{abstract}

Key words groundwater; water quality index; fluoride; nitrate; central Rajasthan, India

\section{INTRODUCTION}

Water quality is an important factor to monitor environment changes which are strongly associated with social and economic development. The evaluation of water in the developing countries has become a critical issue in recent years, especially due to the concern that freshwater will be scarce in the near future. Water from a certain source may be good enough for domestic or industrial use without any treatment, but it may not be suitable for drinking. It may be good for irrigating certain crops, but not for other crops.

It is estimated that about $21 \%$ of communicable diseases in India are water related (Brandon et al. 1995). The water quality issue is now being recognized in India as a major crisis. In most parts of the country, the water supplied through groundwater is beset with problems of quality (CGWB Report 2002). The over dependency on groundwater has led to 66 million people in 22 states being at risk due to excessive fluoride, and around 10 million at risk due to arsenic in six states (Husain et al. 2003, 2013, Ghosh 2007). In addition, there are problems due to excessive salinity, iron, nitrates and others (Desai 1990). Around 195813 inhabitants are affected by poor water quality due to chemical parameters (CPCB 1999). It has been estimated that once pollution enters the subsurface environment it may remain concealed for many years, becoming dispersed over wide areas of groundwater aquifers and rendering groundwater supplies unsuitable for consumption and other uses. The rate of depletion of groundwater levels and deterioration of groundwater quality is of immediate concern in rural areas of the country. The increased dependency on groundwater has made water conservation the top priority in water management studies.

Groundwater occurs almost everywhere beneath the Earth surface. It is not in a single widespread aquifer, but in thousands of local aquifer systems and compartments that have similar characters. Knowledge of the occurrence, replenishment, and recovery of groundwater has special significance in arid and semi-arid regions due to the discrepancy in monsoonal rainfall, insufficient 
surface waters and over drafting of groundwater resources. Groundwater quality depends on the quality of recharged water, atmospheric precipitation, inland surface water, and on sub-surface geochemical processes. Temporal changes in the origin and constitution of the recharged water, hydrologic and human factors, may cause periodic changes in groundwater quality. Water pollution not only affects water quality, but also threatens human health, economic development, and social prosperity (Milovanovic 2007).

\section{STUDY AREA}

Rajasthan is the largest state in India, covering an area of 34.22 million hectares, i.e. $10.5 \%$ of the country's geographical area, but sharing only $1.15 \%$ of its water resources. Most of the state (60$75 \%$ ) is arid or semi-arid. Western Rajasthan is arid to semi-arid, with low and erratic rainfall, high summer temperatures, low humidity and high-velocity wind, a negative water balance and acute water deficit. In the eastern part of the state, the climate is semi-arid to sub-humid with relatively better rainfall, low velocity wind, and higher humidity. Groundwater is overexploited in many districts of the state. The study area includes six centrally located districts of Rajasthan which covers $76546 \mathrm{~km}^{2}$. The study area is shown in Fig. 1 and detail including physical, geological and hydrogeological characteristics is given in Table 1.

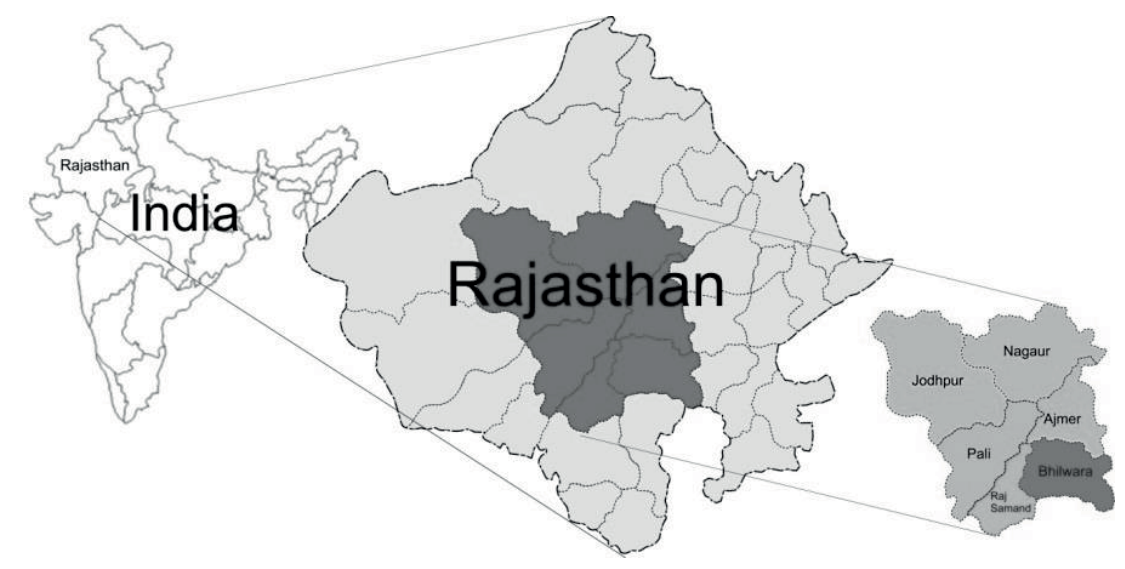

Fig. 1 Study area.

Table 1 Detail of the study area (physical, geological and hydrogeological).

\begin{tabular}{|c|c|c|c|c|c|c|}
\hline \multirow[t]{2}{*}{ District } & \multicolumn{2}{|l|}{ Location } & \multirow{2}{*}{$\begin{array}{l}\text { Area } \\
\mathrm{km}^{2}\end{array}$} & \multicolumn{2}{|c|}{ Population 2011} & \multirow[t]{2}{*}{ Hydrogeology } \\
\hline & Latitude & Longitude & & Urban & Rural & \\
\hline Rajsamand & $\begin{array}{l}24^{\circ} 43^{\prime}- \\
26^{\circ} 01^{\prime}\end{array}$ & $\begin{array}{l}73^{\circ} 28^{\prime}- \\
74^{\circ} 28^{\prime}\end{array}$ & 4655 & 183820 & 972777 & $\begin{array}{l}\text { Alluvium, Schist/phyllite, } \\
\text { Gneiss, Slate, Granite, } \\
\text { Quartzite }\end{array}$ \\
\hline Ajmer & $\begin{array}{l}25^{\circ} 38^{\prime}- \\
26^{\circ} 58^{\prime}\end{array}$ & $\begin{array}{l}73^{\circ} 54^{\prime}- \\
75^{\circ} 22^{\prime}\end{array}$ & 8481 & 1035410 & 1547642 & $\begin{array}{l}\text { Alluvium, Schist, Gneiss, } \\
\text { Granites, Limestone and } \\
\text { Phyllite }\end{array}$ \\
\hline Jodhpur & $\begin{array}{l}25^{\circ} 51^{\prime}- \\
27^{\circ} 37^{\prime}\end{array}$ & $\begin{array}{l}71^{\circ} 48^{\prime}- \\
73^{\circ} 52^{\prime}\end{array}$ & 22850 & 1264614 & 2422551 & $\begin{array}{l}\text { Quaternary alluvium, } \\
\text { Sandstone, Rhyolite, Granite, } \\
\text { Schist and Phyllite. }\end{array}$ \\
\hline Nagaur & $\begin{array}{l}26^{\circ} 25^{\prime}- \\
27^{\circ} 40^{\prime}\end{array}$ & $\begin{array}{l}73^{\circ} 10^{\prime}- \\
75^{\circ} 15^{\prime}\end{array}$ & 17718 & 637204 & 2670539 & $\begin{array}{l}\text { Quaternary Alluvium, } \\
\text { Sandstone, Limestone, } \\
\text { Granite, Schist and Phyllites. }\end{array}$ \\
\hline Pali & $\begin{array}{l}24^{\circ} 45^{\prime}- \\
26^{\circ} 29^{\prime}\end{array}$ & $\begin{array}{l}72^{\circ} 47^{\prime}- \\
74^{\circ} 18^{\prime}\end{array}$ & 12387 & 460006 & 1577567 & $\begin{array}{l}\text { Alluvium, Limestone, } \\
\text { Gneiss, Sandstone, Schist, } \\
\text { Phyllite, Slate, Granite and } \\
\text { Shale }\end{array}$ \\
\hline Bhilwara & $\begin{array}{l}25^{\circ} 01^{\prime}- \\
25^{\circ} 58^{\prime}\end{array}$ & $\begin{array}{l}74^{\circ} 01^{\prime}- \\
75^{\circ} 28^{\prime}\end{array}$ & 10455 & 512654 & 1895869 & $\begin{array}{l}\text { Alluvium, Gneiss, Schist, } \\
\text { Phyllite, Slate, Limestone, } \\
\text { Sandstone and Shale }\end{array}$ \\
\hline
\end{tabular}




\section{QUALITY CRITERIA}

In view of the direct consumption of water by people, domestic water supply is considered to be the most important use of water. Drinking use has been given first priority on utilization of water resource in the National Water Policy. In India, agencies like the Bureau of Indian Standards (BIS) and Indian Council of Medical Research (ICMR) have formulated drinking water standards. According to BIS 10500 (2012), standard values for the basic parameters covered in this paper are given in Table 2.

Table 2 Drinking Water Standards (BIS:10500:2012).

\begin{tabular}{|c|c|c|c|c|}
\hline S. No & Quality parameter & Unit & Requirement* & Permissible limit $^{\#}$ \\
\hline 1 & $\mathrm{pH}$ & & $6.5-8.5$ & No relaxation \\
\hline 2 & Total Dissolved Solids & & 500 & 2000 \\
\hline 3 & Total Hardness & & 200 & 600 \\
\hline 4 & Chloride & & 250 & 1000 \\
\hline 5 & Nitrate & & 45 & No relaxation \\
\hline 6 & Fluoride & $\mathrm{mg} / \mathrm{L}$ & 1.0 & 1.5 \\
\hline 7 & Calcium & & 75 & 200 \\
\hline 8 & Magnesium & & 30 & 100 \\
\hline 9 & Alkalinity & & 200 & 600 \\
\hline
\end{tabular}

*Acceptable limit; \# In the absence of an alternative source.

\section{WATER QUALITY INDEX}

The communication and reporting of ambient water quality data to the average person without compromising the technical integrity of the data, has always been a challenging task. However, reporting of water quality has been made easier in recent years by the development and availability of the Canadian Council of Ministers of the Environment (CCME) Water Quality Index (WQI). It was developed with the intent of providing a tool for simplifying the reporting of water quality data (CCME 2001). It is a tool that provides meaningful summaries of water quality data that are useful to technical and policy individuals, as well as the general public interested in water quality.

The application of the CCME WQI requires Water Quality Guidelines (WQGs). The model essentially consists of three measures of variance from selected WQGs (scope, frequency, amplitude) that combine to produce a value between 0 and 100 that represents the overall water quality. A minimum of four variables must be sampled at least four times to be used in the calculation of index values. The calculation is done in the following steps:

\section{$F_{1}$ (scope)}

$F_{1}$ represents the percentage of variables that do not meet their objectives at least once during the time period under consideration (failed variables), relative to the total number of variables measured:

$$
F_{1}=\left(\frac{\text { Number of Failed Variables }}{\text { Total Number of Variables }}\right) \times 100
$$

\section{$F_{2}$ (frequency)}

$\mathrm{F}_{2}$ represents the percentage of individual tests that do not meet the objectives (failed tests):

$$
F_{2}=\left(\frac{\text { Number of Failed Tests }}{\text { Total Number of Tests }}\right) \times 100
$$

\section{$F_{3}$ (amplitude)}

$\mathrm{F}_{3}$ represents the amount by which failed test values do not meet their objectives. It is calculated in three steps: 
- Step 1 Calculation of Excursion: The number of times by which an individual concentration is greater than (or less than, when the objective is a minimum) the objective is termed an "excursion" and is expressed as follows.

When the test value must not exceed the objective:

$$
\text { excursion }_{i}=\left(\frac{{\text { Failed } \text { Test Value }_{i}}_{\text {objective }_{j}}}{\text { ex }}-1\right.
$$

For the cases in which the test value must not fall below the objective:

$$
\text { excursion }_{i}=\left(\frac{\text { objective }_{j}}{\text { Failed Test Value }_{i}}\right)-1
$$

- Step 2 Calculation of Normalized Sum of Excursions The normalized sum of excursions nse is the collective amount by which individual tests are out of compliance. This is calculated by summing the excursions of individuals' tests from their objectives and dividing by the total number of tests.

$n s e=\frac{\sum_{i=1}^{n} \text { excursion }_{i}}{\text { Numbers of Tests }}$

- Step 3 Calculation of $\boldsymbol{F}_{3}$ It is calculated by an asymptotic function that scales the normalized sum of the excursions from objectives ( $n s e$ ) to yield a range between 0 and 100.

$F_{3}=\left(\frac{n s e}{0.01 n s e+0.01}\right)$

\section{CCME Water Quality Index}

Once the factors have been obtained, the index itself can be calculated by following equation:

$$
C C M E W Q I=100-\left(\frac{\sqrt{F_{1}^{2}+F_{2}^{2}+F_{3}^{2}}}{1.732}\right)
$$

The factor of 1.732 arises because each of the three individual index factors can range as high as 100. This means that the vector length can reach $\sqrt{100^{2}+100^{2}+100^{2}}=\sqrt{30000}=173.2$ as a maximum. Division by 1.732 brings the vector length down to 100 as a maximum; 0 represents the "worst" water quality and 100 represents the "best" water quality. These numbers are divided into

\begin{tabular}{|c|c|c|}
\hline $\begin{array}{l}\text { Quality of } \\
\text { water }\end{array}$ & $\begin{array}{l}\text { CCME-WQI } \\
\text { value }\end{array}$ & Description \\
\hline Excellent & $95-100$ & $\begin{array}{l}\text { water quality is protected with a virtual absence of threat or impairment; } \\
\text { conditions are very close to natural or pristine levels }\end{array}$ \\
\hline Good & $80-94$ & $\begin{array}{l}\text { water quality is protected with only a minor degree of threat or } \\
\text { impairment; conditions rarely depart from natural or desirable levels }\end{array}$ \\
\hline Fair & $65-79$ & $\begin{array}{l}\text { water quality is usually protected, but occasionally threatened or } \\
\text { impaired; conditions sometimes depart from natural or desirable levels }\end{array}$ \\
\hline Marginal & $45-64$ & $\begin{array}{l}\text { water quality is frequently threatened or impaired; conditions often depart } \\
\text { from natural or desirable levels }\end{array}$ \\
\hline Poor & $0-44$ & $\begin{array}{l}\text { water quality is almost always threatened or impaired; conditions usually } \\
\text { depart from natural or desirable levels }\end{array}$ \\
\hline
\end{tabular}
five descriptive categories to simplify presentation (Table 3 ).

Table 3 CCME Water Quality Index categorization.

\section{METHODOLOGY}

Groundwater samples (4369) were collected from 1680 habitations. After the collection, the samples were preserved as per the requirement of the parameters to be analysed. Determination of $\mathrm{pH}$ and conductance was performed on site using a portable meter. For the other parameters, samples were preserved by adding an appropriate reagent and brought to the laboratory in 
sampling kits maintained at $4^{\circ} \mathrm{C}$ for detailed chemical analysis. The physicochemical analysis was performed following standard methods (APHA 2012).

\section{RESULT AND DISCUSSION}

District-wise statistics of groundwater chemistry are presented in Table 4.

$\mathrm{pH}$ values in the study area were within the recommended limit (6.5-8.5). The water in the area is normal to saline and Total Dissolved Solids (TDS) ranges from 110 to $36920 \mathrm{mg} / \mathrm{L}$. High fluoride (up to $30 \mathrm{mg} / \mathrm{L}$ ) in the area is due to leaching of fluoride rich minerals (fluorite) and rocks (viz. granite and gneiss) dominantly present in the study area (Srinivasamoorthy et al. 2007). The easier accessibility of rainwater to weathered rock, long-term irrigation processes, semi-arid climate, and long residence time of groundwater enriches the fluoride in the groundwater of the area (Srinivasamoorthy et al. 2008). Nitrate is higher (up to $800 \mathrm{mg} / \mathrm{L}$ ) may be due to leaching from plant nutrient and nitrate fertilizers (Freeze and Cherry 1979, Madison and Brunett 1984). District-wise, the three habitations with the maximum concentrations of fluoride, nitrate and TDS are presented in Table 5.

CCME WQI in all districts is calculated and is shown in Table 6. Figure 2 shows a contour map for WQI in the study area. WQI in the study area ranges from 20.43 to 100 . The minimum WQI is found in Salwa Kalan of Mandore block of Jodhpur District.

Table 4 Statistics of groundwater chemistry.

\begin{tabular}{|c|c|c|c|c|c|c|c|c|c|c|c|c|c|c|c|c|}
\hline \multirow[t]{2}{*}{ District } & \multicolumn{2}{|c|}{ Fluoride } & \multicolumn{2}{|c|}{ Nitrate } & \multicolumn{2}{|l|}{ TDS } & \multicolumn{2}{|c|}{ Chloride } & \multicolumn{2}{|l|}{$\mathrm{TH}$} & \multicolumn{2}{|c|}{ Calcium } & \multicolumn{4}{|c|}{ Magnesium Alkalinity } \\
\hline & Mil & $\operatorname{Max}$ & Min & Max & Min & Max & Min & Max & Min & Max & 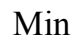 & $\operatorname{lax}$ & $\mathrm{Min}$ & Max & Min & Max \\
\hline ais & 0.2 & 7.5 & 0 & 0 & 227 & 4540 & 50 & 2 & 50 & 1770 & 8 & 840 & & 648 & 84 & 97 \\
\hline ji & 2 & 15 & .0 & 1 & 190 & 22 & 20 & & 5 & & & & & & 71 & 121 \\
\hline d & .1 & 30.0 & .2 & 0 & 120 & 0 & 0 & 18 & 70 & & & & & 0 & 0 & 136 \\
\hline & 1 & 25.0 & 10 & 77 & 149 & & 1 & & 50 & 38 & 12 & & 2 & 17 & 2 & 1270 \\
\hline ali & 0.2 & 23.2 & 20 & 240 & 170 & 0 & 2 & 5 & 70 & 48 & 8 & 10 & & 648 & 60 & 1400 \\
\hline hil & 0.1 & 19.5 & 0.1 & 700 & 110 & 29000 & 20 & 19800 & 60 & 9400 & 8 & 2040 & 4.8 & 1320 & 60 & 900 \\
\hline
\end{tabular}

Values in $\mathrm{mg} / \mathrm{L}$.

Table 5 Top three habitations with maximum concentration of contaminants.

\begin{tabular}{lllllll}
\hline District & Fluoride & & Nitrate & & TDS \\
& Value & Habitation & Value & Habitation & Value & Habitation \\
\hline Rajsamand & 7.5 & Sadri & 120 & Sakarda & 4540 & Aidena \\
& 6.3 & Kushal Pura & 100 & Chokri & 3208 & Ghosundi \\
& 5.9 & Sadri & 95 & Aidena & 3170 & Sakarawas \\
Ajmer & 15.1 & Goyla & 791 & Paner & 22600 & Para \\
& 12.1 & Katsoora & 757 & Hathi Khera & 20100 & Jooniya \\
& 8.7 & Goyla & 751 & Khatoli & 5090 & Kanpura \\
Jodhpur & 30 & Chowkari Kalla & 800 & Khatiyasni & 36920 & Soorpura \\
& 18 & Bhavi & 600 & Kheri Salwa & 19110 & Hariyada \\
& 19.4 & Tilwasani & 500 & Daikara & 19010 & Dhundhara \\
Nagour & 25 & Alakh Pura & 677 & Gogelao & 16100 & Chhapra \\
& 22.2 & Ganthilasar & 610 & Loonsara & 11250 & Barani \\
& 14.8 & Ganthilasar & 526 & Manjhee & 10300 & Gogelao \\
Pali & 23.2 & Khor & 240 & Parasla Kalan & 11200 & Dhani \\
& 20.3 & Chotila & 220 & Sewari & 11200 & Deeri \\
& 19.4 & Anandpur Kalu & 180 & Neepal & 10325 & Roopawas \\
Bhilwara & 19.5 & Balapura & 700 & Palri & 29000 & Sangariya \\
& 16.0 & Amarwasi & 500 & Rayla & 24300 & Bansera \\
& 15.0 & Barantiya & 500 & Ban Ka Khera & 23700 & Kanechhan Khurd \\
\hline
\end{tabular}

All the values in $\mathrm{mg} / \mathrm{L}$ 
Table 6 Classification of habitations based on CCME WQI.

\begin{tabular}{|c|c|c|c|c|c|c|c|c|c|c|c|}
\hline \multirow[t]{2}{*}{ District } & \multirow[b]{2}{*}{ 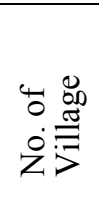 } & \multirow[b]{2}{*}{ 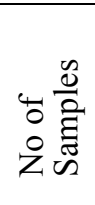 } & \multicolumn{3}{|c|}{ WQI Factors (Max) } & \multicolumn{2}{|l|}{ WQI } & \multirow[b]{2}{*}{ 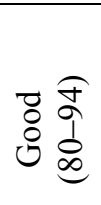 } & \multirow[b]{2}{*}{ 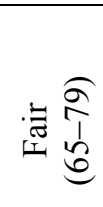 } & \multirow[b]{2}{*}{ 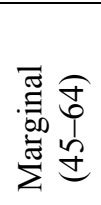 } & \multirow[b]{2}{*}{ 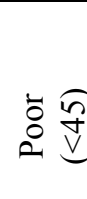 } \\
\hline & & & $\mathrm{F}_{1}$ & $\mathrm{~F}_{2}$ & $\mathrm{~F}_{3}$ & Min & 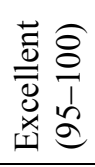 & & & & \\
\hline Rajsamand & 162 & 418 & 71.43 & 40.91 & 32.12 & 51.70 & 43 & 65 & 35 & 19 & 0 \\
\hline Ajmer & 224 & 623 & 88.89 & 50 & 77.97 & 35.46 & 13 & 89 & 55 & 54 & 13 \\
\hline Jodhpur & 236 & 575 & 88.89 & 70 & 74.87 & 20.43 & 28 & 86 & 47 & 52 & 23 \\
\hline Nagaur & 429 & 1154 & 88.89 & 67.86 & 71.97 & 21.34 & 34 & 146 & 118 & 97 & 34 \\
\hline Pali & 294 & 804 & 88.89 & 74.07 & 64.68 & 26.60 & 56 & 105 & 67 & 54 & 12 \\
\hline Bhilwara & 335 & 795 & 88.89 & 60 & 80.96 & 30.79 & 93 & 117 & 47 & 67 & 11 \\
\hline Total & 1680 & 4369 & 71.43 & 41 & 81 & 20.43 & 267 & 608 & 369 & 343 & 93 \\
\hline
\end{tabular}

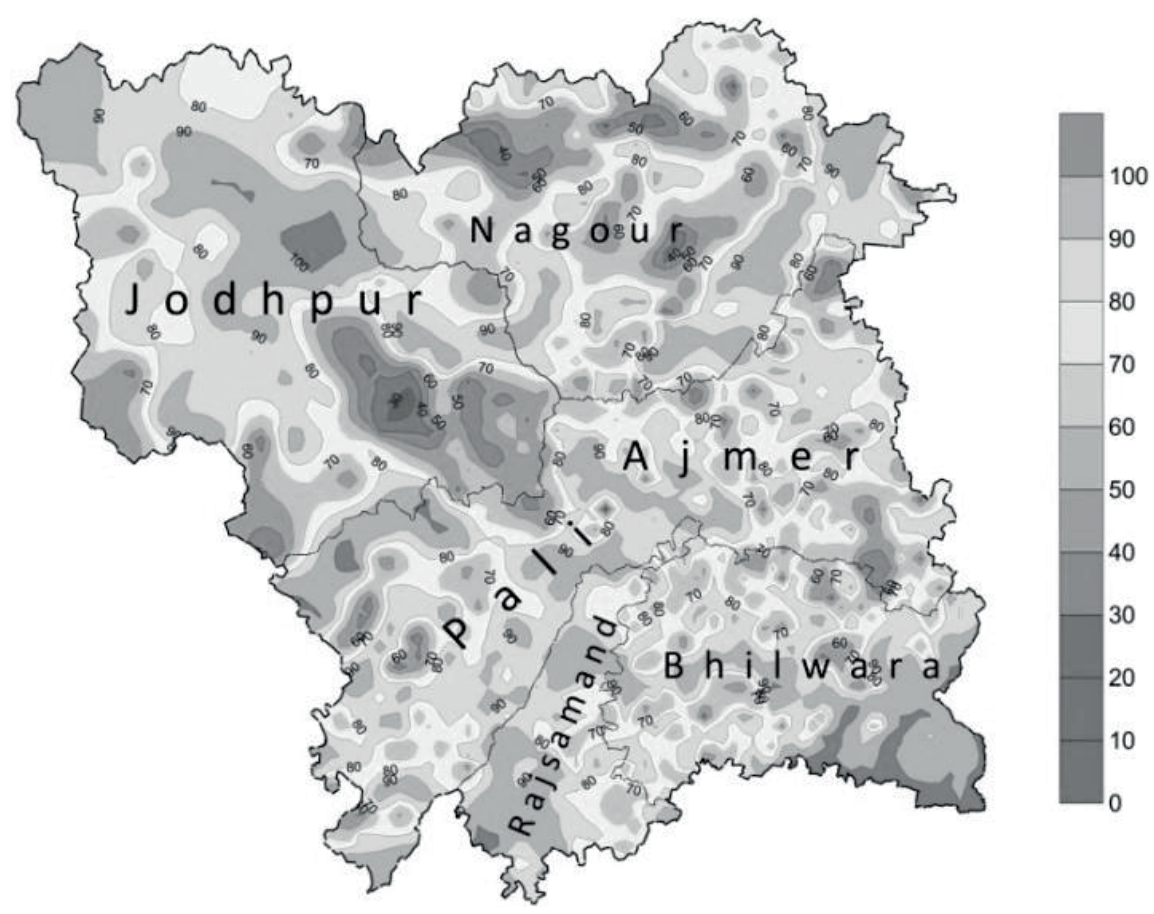

Fig. 2 Contour map for study area.

From the results it is clear that Rajsamand district has no habitations with poor groundwater quality; however, 19 habitations are marginal and 35 are fair in quality. The most quality affected district is Nagaur with 34 habitations in poor, 97 habitations in marginal and 118 habitation in fair category of CCMEWQI. Only 34 habitations are in the excellent category. $\mathrm{F}_{1}$ (Scope) represents the number of parameters failed in a habitation. In the study area in all districts except Rajsamand, $88.89 \%$ parameters were found above standard limit for a habitation. $\mathrm{F}_{2}$ (frequency) represents number of tests failed for a habitation. In Pali district it is maximum, where $74.07 \%$ tests are failed for a habitation. $F_{3}$ (Amplitude) represents the amount which is higher than the standard limit. In Bhilwara district the values are $80.96 \%$ above the standard for a habitation.

\section{CONCLUSION}

The results indicate that most of the water quality parameters were beyond the permissible limits. The overall view of the Water Quality Index of the present study zone had a low WQI value indicating poor water quality. A total of $70 \%$ parameters were found unsafe in the area, with at least $50 \%$ failed test results. No district can be marked safe for use of groundwater among the six districts. Central government is now concentrating on the $78 \%$ rural population by launching a national 
program, "National Rural Drinking Water Program" with a target to provide safe and sustainable drinking water. The first priority is focused on the coverage of quality affected habitations.

\section{REFERENCES}

APHA (2012) Standard Methods for the Examination of Water and Wastewater (20th edn). American Public Health Association. Washington, DC.

Brandon, C and Homman, K. (1995) The cost of inaction: Valuing the economy wide cost of environmental degradation in India. Asia Environmental Division, World Bank, October, 07, memo.

CCME (2001) Canadian water quality guidelines for the protection of aquatic life. Water Quality Index 1.0, Technical Report. In Canadian environmental quality guidelines, 1999; Canadian Council of Ministers of the Environment, Winnipeg.

CGWB (2002) Technical Report. Central Groundwater Board of India, 38.

CPCB (1999) Water Quality status and statistics1996-97.Central Pollution Control Board, New Delhi.

Desai, B. (1990) Pollution in India: Law and Enforcement. Lancers Books, New Delhi.

Freeze, R. A. and Cherry, J. A. (1979). Groundwater. New Jersey: Prentice Hall.

Ghosh, A. (2007) Current knowledge on the distribution of arsenic in groundwater in five states of India. J. Environ. Sci. Health. Part A 42, 1-12.

Husain, I., et al. (2003) Fluoride in Drinking Water and Health Hazards: Some Observations of Fluoride Distribution in Rajasthan. In: Environmental Scenario for 21st Century (ed. by S. K. Agarwal), 355-374. APH Publishing Corporation.

Hussain, J., Husain, I. and Arif, M. (2013) Fluoride contamination in groundwater of central Rajasthan, India and its toxicity in rural habitants. Toxicological \& Environmental Chemistry (95)6, 1048-1055 (DOI: 10.1080/02772248.2013.832545).

Madison, R. J. and Brunett, J. O. (1984) Overview of the occurrence of nitrate in ground water of the United States, in National Water Summary. US Geological Survey, Water Supply Paper 2275.

Milovanovic, M. (2007) Water quality assessment and determination of pollution sources along the Axios / Vardar River, Southeastern Europe. Desalination 213, 159-173.

Srinivasamoorthy, K., et al. (2007) Control of rock weathering on the chemical composition of groundwater in Salem District, Tamilnadu, India. International Journal of Physical Sciences 19(3), 367-378.

Srinivasamoorthy, K., et al. (2008) Identification of major sources controlling Groundwater Chemistry from a hard rock terrain - a case study from Mettur taluk, Salem district, Tamilnadu, India. Journal of Earth System Sciences 117(1), 49-58. 